\title{
Gradient Analysis of Vegetation Dominated by Two Sub- species of Big Sagebrush
}

\author{
MARK L. SHUMAR AND JAY E. ANDERSON
}

\begin{abstract}
Stands of vegetation dominated by basin big sagebrush (Artemisia tridentata Nutt. subspecies tridentata) intergrade with stands dominated by Wyoming big sagebrush (A rtemisia tridentata Nutt. subspecies wyomingensis) on the Idaho National Engineering Laboratory in southeastern Idaho. Detrended correspondence analysis and correlation were used to elucidate potential relationships between vegetation patterns and soil factors along a gradient from stands having only the subspecies tridentata to stands having only the subspecies wyomingensis. Distributions of the subspecies were consistently associated with gradients in soil texture. Basin big sagebrush was most abundant on sandy soils and Wyoming big sagebrush was dominant on finer textured soils. Mixed stands occurred on central portions of the gradient. Similar results for 3 study areas were observed, despite differences in soil texture between areas. Thus, the distributional patterns are associated with changes in soil texture rather than actual amounts of sand, silt, or clay.
\end{abstract}

Sagebrush shrublands of the Intermountain West and Great Basin regions are managed for a variety of uses, such as livestock grazing, wild life habitat, and recreational activities. Because management practices often affect biotic and abiotic components of the environment, the relationships between various plant species on these shrublands and the environmental factors that the plants

Authors are senior research assistant and professor, Department of Biological Sciences, Idaho State University, Pocatello 83209.

Authors thank Dr. O.D. Markham for his support, N. Cole and D. Pavek for field assistance, D. Floyd and S. Strahm for computer assistance, $M$. Jensen for soil profile descriptions, and Dr. R. Nowak and two anonymous reviewers for reviewing the manuscript. This paper is a contribution from the Idaho National Engineering Laboratory Ecological Studies Program, supported by the Office of Health and Environmental Research, U.S. Department of Energy, contract no. DE-AS07-76ID01529.

Manuscript accepted 7 August 1985. experience is of interest. The relationships between Artemisia species and environment have commanded particular attention. Distributions of various species of Artemisia are correlated with a variety of soil and climatic factors (e.g., Robertson et al. 1966, Fosberg and Horonaka 1964, Sabinske and Knight 1978, West et al. 1978).

A study of sagebrush distribution at the Idaho National Engineering Laboratory (INEL) in southeastern Idaho (Shumar 1983) identified both pure and mixed stands of basin big sagebrush (Artemisia tridentata Nutt. subspecies tridentata; Beetle 1960) and Wyoming big sagebrush (Artemisia tridentata Nutt. subspecies wyomingensis; Bectle and Young 1965). (Pure refers to species assemblages containing one subspecies or the other but not both; mixed stands contain both subspecies.) The size of the basin big sagebrush stands was unexpected because previous reports suggested that the expansive lava flows and flats of the upper Snake River Plain were predominantly occupied by Wyoming big sagebrush (Harniss and West 1973, McBride et al. 1978) and contained "patches" of basin big sagebrush (Winward 1970). However, some of these basin big sagebrush patches on the INEL may be as large as $65 \mathrm{~km}^{2}$ (Shumar 1983).

General descriptions of the soil properties associated with the distributions of basin big sagebrush and Wyoming big sagebrush occur in the literature. Basin big sagebrush occurs on deep (Beetle 1960, Hironaka 1978, Winward and Tisdale 1977), well-drained (Tisdale and Hironaka 1981), often sandy soils (Morris et al. 1976), in valley bottoms, on foothills, or along drainages. Its distribution often coincides with high water tables or deep moisture accumulations (Morris et al. 1976). Wyoming big sagebrush can be found on moderately deep to shallow soils (Hironaka 1978) of medium texture that often limit water penetration (Morris et al. 1976). These plants sometimes occur on immature soils (Morris et al. 
1976) or slightly saline soils (Tisdale and Hironaka 1981). This subspecies is found on lower slopes of major drainages (Winward and Tisdale 1977) or on hilltops and flats (Beetle and Young 1965).

Because of the extent of the pure and mixed stands of the 2 sagebrush subspecies on the INEL, and because of the generalized nature of the information on their relationships to environment, it seemed that an intensive study employing ordination procedures might provide insights into the factors affecting their distributions. The objective of this study was to generate hypotheses about relationships between the distributions of the sagebrush subspecies and characteristics of the soil using ordination and correlation analyses.

\section{Study Area}

The INEL occupies $2,315 \mathrm{~km}^{2}$ of the upper Snake River Plain near the southeastern ends of the Lemhi and Lost River mountain ranges in eastern Idaho. Soils of the INEL are primarily aeolian sands and loess and are derived from silicic volanics and paleozoic rocks from the surrounding mountains (McBride et al. 1978).

The climate is semiarid and principally affected by the rainshadow of the central Idaho mountains (Harniss and West 1973). The average annual precipitation is $21 \mathrm{~cm}$ and the average annual temperature is $5.5^{\circ} \mathrm{C}$ (Anderson and Holte 1981). The average frost-free period is 91 days (Harniss and West 1973).

The vegetation of the INEL is primarily sagebrush-bunchgrass associations, although the other shrubs (Chrysothamnus viscidiflorus (Hook.) Nutt., Ceratoides lanata (Pursh) J.T. Howell, Tetradymia canescens DC., Atriplex confertifolia (Torr. and Frem.) Wats., Atriplex nuttallii Wats., Leptodactylon pungens (Torr.) Nutt., and Gutierrezia sarothrae (Pursh) Britt. and Rusby.) are locally important (McBride et al. 1978, Anderson and Holte 1981). The common grass species are Elymus elymoides (Raf.) Sweezy, Psuedorogeneria spicata (Pursh) A. Love, Elymus lanceolatus (Scribner and J.G. Smith) Gould, Oryzopsis hymenoides (R. and S.) Ricker, Stipa comata Trin. and Rupr., and Leymus cinereus (Scribn. and Merrill.) (Anderson and Holte 1981). Additional information on the past use of the area can be found in Harniss and West (1973) and Anderson and Holte (1981).

Three areas, each containing pure and mixed stands of basin big sagebrush and Wyoming big sagebrush, were selected for study. The first area included the southeastern ends of 4 rows of sand dunes (identified as D-1, D-2, D-3, and D-4). Each dune row was a complex of linear, stabilized dunes that extended in a northeasterly direction across a large flat basin. Basin big sagebrush occurred as pure stands on the dunes, Wyoming big sagebrush occurred as pure stands on the slacks (areas between dune rows with little or no sand), and mixed stands of both subspecies occurred on dune margins. Soils of this area were generally loams and dune sands. Although only D-4 was within an area closed to livestock grazing, only $\mathrm{D}-1$ had evidence of recent sheep grazing.

The second study area, T-22, was on the northern-most extension of a large lava flow that covers most of the eastern part of the INEL. The area was characterized by deep sand accumulations in swales between lava ridges. A mosaic of pure and mixed stands of Wyoming big sagebrush and basin big sagebrush was associated with the undulating pattern of the lava surface. Soils ranged from sandy loams to sands. This area probably had been grazed by sheep in the recent past.

The third study area, T-24, was in an eastern extension of a large depression surrounded by lava flows. Pure and mixed stands of basin big sagebrush and Wyoming big sagebrush formed a mosaic pattern on the bottom and sides of this depression. Soils of this area were mostly sandy loams, but ranged from silt loams to sands. This site was within an area closed to grazing since at least 1957.

\section{Methods and Materials}

\section{Vegetation Sampling}

Vegetative cover at each study area was estimated by point interception. Twenty point frames (Floyd and Anderson 1982) placed systematically at $2.5-\mathrm{m}$ intervals along a $50-\mathrm{m}$ transect constituted a sampling unit. Floyd (1982) determined that 20 frames in sagebrush-grass vegetation provided a reasonably accurate and expedient estimate of cover for all but the rarest species.

At the 4 dune complexes, baselines were established perpendicular to the long axis of the dune rows. The baselines extended from the slack on one side of the dune row to the slack on the other side. Transects were placed at regular intervals perpendicular to the baseline (parallel to the long axis of the dune row) such that the dunes and the slacks on both sides would be sampled. The 4 dune complexes contained $8,7,14$, and 9 transects (D-1, D-2, D-3, and D-4 respectively), all at 50-m intervals.

At the T-22 study area, a baseline was placed in a southeastnorthwest direction and traversed approximately $1,500 \mathrm{~m}$ of the north edge of the lava flow. Thirty transects were established perpendicular to this baseline at $50-\mathrm{m}$ intervals. The transects paralleled the long axes of the lava ridges and depressions. Some transects were more or less than $50 \mathrm{~m}$ apart to avoid crossing sharp changes in topography.

The T-24 study area included 21 transects at $50-\mathrm{m}$ intcrvals. Twenty were placed perpendicular to a baseline that began at the bottom of the depression and extended in a northeasterly direction, up a lava ridge, across a plateau, to the base of a second lava ridge. Transect 21 was south of the baseline on the second lava ridge. Again, transects were placed such that they ran parallel to the lava ridges.

\section{Soll Sampling}

Soil profiles were described and soil samples were taken from pits placed in an open area between shrubs. Soil pits were dug at 4 transects at $\mathrm{D}-4,15$ transects at $\mathrm{T}-22$, and 12 transects at $\mathrm{T}-24$. These transects were chosen on the basis of apparent vegetal differences to reduce the effort involved in sampling at every transect. Profile descriptions included texture, structure, consistency, horizon depth and classification, $\mathrm{pH}$, moist and dry colors, root size and amount, and percent rock.

Soil samples were put into plastic bags and taken to the laboratory for soil nutrient analyses. At least one sample was taken from the A horizon(s) and at least one from the B horizon(s).

\section{Laboratory Soil Analyses}

The following soil analyses were performed by the Soils Laboratory, Department of Agronomy and Horticulture, Brigham Young University: electrical conductivity, cation exchange capacity, and exchangeable ions (phosphorus, calcium, magnesium, potassium, and sodium). Percent nitrogen, determined by the macro-Kjeldahl method (Black et al. 1965b), and percent sulfur (Tiedemann and Anderson 1971) were measured by the USDA Intermountain Forest and Range Experiment Station Shrub Sciences Laboratory in Provo, Utah, on all A horizons. We conducted the remaining analyses: percent organic carbon, determined by the Walkey-Black method (Black et al. 1965b), was analyzed for all A horizons. Particle size fractions were determined for all horizons by the hydrometer method (Black et al. 1965a).

\section{Analysis of Data}

Data for each study area were ordinated using detrended correspondence analysis (DCA) on cover values for all vascular plant species (Hill and Gauch 1980). Ordination is a technique of data exploration that reduces large matrices of sample-by-species data to graphs showing one or more axes of variation. Ordination reflects the patterns of variation of the species in the samples; these patterns are then subject to interpretation and correlation with environmental factors by the investigator (Peet and Loucks 1977, Gauch 1982). DCA is essentially the same as reciprocal averaging (RA) except that additional mathematical processes are added to correct some of the problems of RA. Both DCA and RA use an iterative mathematical process that simultaneously weights samples and species such that a sample weight is the average of all the species weights in that sample and reciprocally a species weight is 
the average of all the sample weights in which that species is found (Hill 1973).

RA has 2 shortcomings. The second axis of variation is a quadratic function of the first and thus produces an "arch" or "horseshoe" shape in 2 dimensions that may have no ecological meaning (Hill 1973). Also, sample distances in the middle of the RA ordination field may not reflect the same degree of variation as the sample distances at the ends of the field (Hill and Gauch 1980). DCA corrects these 2 shortcomings of RA by dividing the first axis into segments and adjusting the axis 2 scores in each segment to eliminate the "arch" effect (a process known as "detrending") and by "rescaling" within-sample species scores to equalize sample distances (Hill and Gauch 1980, Gauch 1982). However, Beals (1984) reported that one of the sources of the "arch" effect is bimodality of species distributions along environmental gradients, and hence, is the result of an ecological phenomenon. Thus, detrending of the second axis may result in loss of ecological information. DCA may also be overly sensitive to rare species and outlier samples in the data set, which may obscure overall patterns (Beals 1984).

Our ordinations were produced by the program DECORANA using the default values for rescaling, number of segments, and rescaling threshold (Hill 1979). Both DCA and RA ordinations of the data sets were produced and compared. In each case, the DCA results were similar to the RA results except for the elimination of arch shapes. We concluded that DCA, at the default settings, was adequate because of the consistency of the DCA and RA results, and, even though the arch may be the result of bimodal species distributions, the DCA results were interpretable in terms of the major axis of variation in the vegetation.

Spearman's correlation coefficients $\left(\mathbf{R}_{\mathrm{s}}\right)$ were calculated using the DCA axis values for transects having a soil pit and the complementary soil nutrient and physical factor data. Those variables that were significantly correlated (alpha $=0.05$ ) with the axis values are reported. The ordination axes were developed taking all species into account, not just the sagebrush subspecies. Thus, the correlations reflect changes in entire plant assemblages that are dominated by one sagebrush subspecies or the other.

It is important to note that it is impossible to determine cause and effect relationships with correlation. Our goal in using ordination and correlation is to elucidate potential relationships between environment and species, which in turn would need to be tested in some other manner.

\section{Results}

The ordinations for the three study areas produced similar results with respect to the subspecies distributions. In each case, the first axis (in the T-24 ordination, both axes 1 and 2) showed a gradient in shrub vegetation from one subspecies to the other (Figs. 1 and 2).

The ordination of the T-22 study area included all 30 transects and 27 species. Total variation that was explained by axes 1 and 2 was $64 \%$ and $25 \%$, respectively. Cover of basin big sagebrush decreased from left to right on axis 1 while that of Wyoming big sagebrush increased, resulting in a zone of co-occurrence of the two subspecies at the center of the axis (Fig. 1).

Spearman's Rank test indicated that percent silt, nitrogen, and cation exchange capacity were positively correlated with axis 1 (Table 1). Percent sand was correlated negatively with axis 1, but it changed only slightly from $90 \%$ at the basin big sagebrush end to $73 \%$ at the Wyoming big sagebrush end of the axis (Fig. 1). Although clay content was low at all transects, there was a tendency for textures to become finer from left to right along axis 1 , and this corresponded with the change in the dominant shrub from basin big sagebrush at the sandy end to Wyoming big sagebrush at the finer textured end (Fig. 1).

The ordination for the T-24 study area included all 21 transects and 33 species. Axes 1 and 2 explained $46 \%$ and $17 \%$ of the variation, respectively. Basin big sagebrush was the dominant

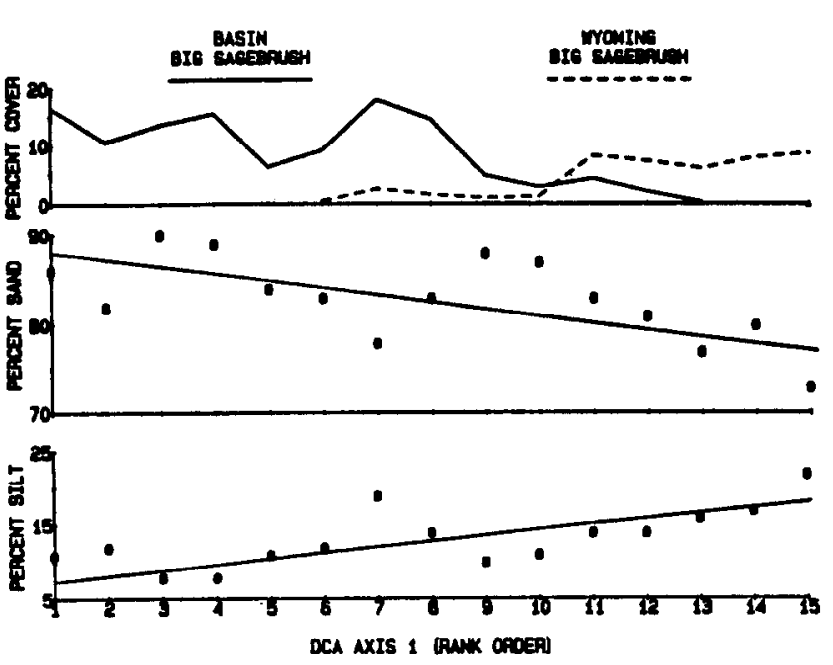

Fig. 1. Relative cover of the 2 sagebrush subspecies (top), percent sand in the soil (middle), and percent silt in the soil (bottom) plotted as a function of the first DCA axis for the T-22 study area.

shrub at this study area, occurring on 20 of the transects and having the highest cover on 18 transects. Wyoming big sagebrush occurred on 15 transects but was dominant on only 3 of them. Where the 2 subspecies co-occurred, Wyoming big sagebrush was generally subordinant.

Table 1. Spearman's rank correlation coefficients (Rs) for variables significantly correlated $(P<0.05)$ with ordination axis values for the T-22 and T-24 study areas. (CEC = cation exchange capacity, $O C=$ organic carbon)

\begin{tabular}{cccc}
\hline & T-22 AXIS 1 & \multicolumn{2}{c}{ T-24 AXIS 2 } \\
\hline Variable & Rs & Variable & Rs \\
\hline CEC & $.59^{*}$ & Ca & $.89^{* * *}$ \\
N & $.62^{*}$ & Mg & $.75^{* *}$ \\
Sand & $-.61^{*}$ & OC & $.90^{* * *}$ \\
Silt & $.68^{* *}$ & N & $.85^{* * *}$ \\
& & S & $.78^{* *}$ \\
& & Sand & $-.86^{* * *}$ \\
& & Silt & $.80^{* *}$ \\
\hline
\end{tabular}

$*, * * ; * *$ Significant at the $0.05,0.01$, and 0.001 levels, respectively.

The sequence of transects, arranged by the ordination program, was similar for both axes 1 and 2 . The distributions of the 2 subspecies along axis 2 was similar to that of axis 1; basin big sagebrush cover decreased and Wyoming big sagebrush cover increased from low axis values to high axis values (Fig. 2). This distributional pattern was similar to axis 1 of the T-22 study area.

No soil parameters were significantly correlated with axis 1 , however amounts of calcium, magnesium, organic carbon, nitrogen, and sulfur in the A horizon, as well as percentages of sand and silt, were correlated with the second axis (Table 1). The distributions of the sagebrush subspecies on both axes were similar, thus their relationship to soil nutrients were still discernable. The nutrients listed above and percent silt were positively associated with axis 2 values; percent sand was negatively correlated with axis 2 . Basin big sagebrush occurred on sandier soils and Wyoming big sagebrush was found on finer textured soil (Fig. 2). It should be noted that textures of soils at T-24 were finer than those at T-22. Mean sand and silt percentages differed significantly between the 
$T-22$ and $T-24$ study areas $(t=3.14$ and $t=3.05$, respectively; $n=$ 25 ). This did not, however, preclude the existence of a soil texture gradient that was significantly correlated with an ordination axis.

The ordination of the Dunes study area included 38 transects (D1 [8] + D2 [7] + D3 [14] + D4 [9]) from the 4 dune complexes and a total of 36 species. Axes 1 and 2 explained $57 \%$ and $20 \%$ of the variation in the vegetation, respectively. From left to right along the first axis, DCA separated the transects according to landscape position (i.e., dune tops, dune margins, and slacks). Basin big sagebrush had the highest cover on the dunes, lower cover on the margins, and was generally absent on the slacks. Wyoming big sagebrush cover was greatest on the slacks. Both sagebrush subspecies co-occurred with about equal but low cover at the center of the axis (i.e., dune margins).

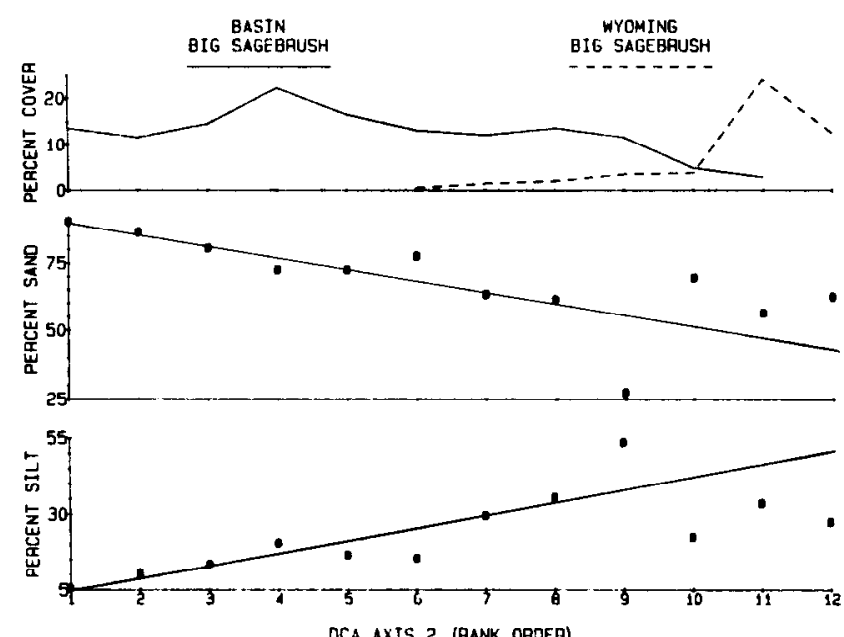

Fig. 2. Relative cover of the 2 sagebrush subspecies (top), percent sand in the soil (middle), and percent silt in the soll (bottom) plotted as a function of the second DCA axis for the T-24 study area.

The small sample size (4) of soils at the Dunes study area precluded environmental correlation; however, observation suggested that the first axis represented a soil texture gradient from areas of deep sand accumulations (dune tops) to areas with silty soil and no loose sand (slacks).

\section{Discussion}

The results of the DCA ordinations for the 3 study areas suggested that basin big sagebrush occupied the sandy end of a soil texture gradient Wyoming big sagebrush occupied the finer textured end (Figs. 1 and 2). Although the actual amounts of sand and silt differed among the study areas, the subspecies still responded to the changes in soil texture. For example, sand percentages of the T-22 study area were greater than those of the T-24 study area (Figs. 1 and 2), but the change in sand percentages was significantly related to the change from stands dominated by one sagebrush subspecies to stands dominated by the other at both study areas (Table 1). The changes in subspecies distributions sometimes occurred with slight changes (less than 20\%) in sand or silt. Apparently, on these soils where both sagebrush subspecies have had access to the area, the subspecies have partitioned themselves on a textured gradient regardless of actual amounts of sand and silt.

A possible mechanism for this separation is competition for soil moisture, which we presume is more available in sandy soil. Sand dunes may be relatively mesic because of deep moisture infiltration, high storage capacity, and low evaporative loss as compared to finer textured arid and semiarid soils (Barnes and Harrison 1982, Bowers 1982, Tevis 1958, Pavlik 1980, Kirkpatrick and Hutchinson 1980).
Other soil characteristics, such as soil depth and nutrient concentrations, can also change concomitantly with the soil texture gradient. Measured soil depths were not correlated with the ordination axes, but they were difficult to determine accurately because of possible fissures in the lava rocks. We observed that silt soils were often aggregated and compact, whereas sandy soils were soft and often deep. Soil depth, probably because of its relationship to soil moisture, may influence the distributions of the sagebrush subspecies (Hironaka 1978, Winward and Tisdale 1977, Morris et al. 1976).

Nitrogen and cation exchange capacity increased with increasing silt at the T-22 study area, and calcium, magnesium, organic carbon, nitrogen, and sulfur increased with increasing silt at the T-24 study area. Thus, more nutrients may have been in the soil near Wyoming big sagebrush plants than near basin big sagebrush plants. This is contrary to previous information that indicates higher nutrients under basin big sagebrush communities (Winward 1970). We suspect that higher nutrients in our study were affected by the nutrients binding to finer textured soils, and were probably leached from sandy soils. Whether or not nutrients were more available to plants at the fine textured end as opposed to the sandy end of the soil texture gradient is not known.

This study was designed to elucidate potential relationships between the 2 sagebrush subspecies and environment in an objective manner. We suggest that the subspecies arc responding to slight changes in soil texture, which presumably is related to soil water availability, regardless of actual amounts of sand and silt. This suggestion would have to be tested directly to be conclusive, but the hypothesis is consistent with the general observations made by others.

\section{Literature Cited}

Anderson, J.E., and K.E. Holte. 1981. Vegetation development over 25 years without grazing on sagebrush-dominated rangeland in southeastern Idaho. J. Range Manage. 34:25-29.

Barnes, P.W., and A.T. Harrison. 1982. Species distribution and community organization in a Nebraska sandhills mixed prairie as influenced by plant/soil-water relationships. Oecologia 52:192-201.

Beals, E.W. 1984. Bray-Curtis ordination: An effective strategy for the analysis of multivariate ecological data. p. 1-55. In: MacFadyen. A. and E.D. Ford (eds.) Advances in Ecological Research. Vol. 14. Academic Press. New York.

Beetle, A.A. 1960. A study of sagebrush: The section Tridentatae of Artemisia. Univ. of Wyoming Agr. Exp. Sta. Bull. No. 368.

Beetle, A.A. and A. Young. 1965. A third subspecies in the Artemisia tridentata complex. Rhodora 67:405-406.

Black, C.A., D.D. Evans, J.L. White, L.E. Ensminger, and F.E. Clark. 1965a. Methods of soil analysis. Part 1. Agronomy No. 9. Amer. Soc. Agron. and Amer. Soc. Testing Mater. Madison, Wis.

Black, C.A., D.D. Evans, J.L. White, L.E. Ensminger, and F.E. Clark. 1965b. Methods of Soil Analysis. Part 2. Agronomy No. 9. Amer. Soc. Agron. and Amer. Soc. Testing Mater. Madison, Wis.

Bowers, J.E. 1982. The plant ecology of inland dunes in western North America. J. Arid Environ. 5:199-220.

Floyd, D.A. 1982. A comparison of three methods for estimating vegetal cover in sagebrush steppe communities. M.S. Thesis. Idaho State Univ. Pocatello.

Floyd, D.A. and J.E. Anderson. 1982. A new point interception frame for estimating cover of vegetation. Vegetatio 50:185-186.

Fosberg, M.A. and M. Hironaka. 1964. Soil properties affecting the distribution of big and low sagebrush communities in southern Idaho. Forage Plant Physiology and Soil-Range Relationships. Amer. Soc. Agron. Spec. Pub. No. 5:230-236.

Gauch, H.G., Jr. 1982. Multivariate analysis in community ecology. Cambridge University Press. Cambridge.

Harniss, R.O., and N.E. West. 1973. Vegetation patterns of the National Reactor Testing Station, southeastern Idaho. Northwest Sci. 47:30-43.

Hill, M.O. 1973. Reciprocal averaging: an eigenvector method of ordination. J. Ecol. 61:237-249.

Hill, M.O. 1979. Decorana. A FORTRAN program for detrended correspondence analysis and reciprocal averaging. Ecology and Systematics. Cornell Univ. Ithaca. 
Hill, M.O., and H.G. Gauch. 1980. Detrended correspondence analysis: an improved ordination technique. Vegetatio 42:47-58.

Hironaka, M. 1978. Basic synecological relationships of the Columbia River sagebrush type. p. 27-32. In: Gifford, G.F., F.E. Busby, and J.D. Shaw. (eds.) Sagebrush Ecosystem Symposium. Utah State University Press, Logan.

Kirkpatrick, J.B., and C.F. Hutchinson. 1980. The environmental relationships of Californian coastal sage scrub and some of its component communities and species. J. Biogeography 7:23-38.

McBride, R., N.R. French, A.H. Dahl, and J.E. Detmer. 1978. Vegetation types and surface soils of the Idaho National Engineering Laboratory Site. IDO-12084. Nat. Tech. Info. Serv. Springfield, Va.

Morris, M.S., R.G. Kelsey, and D. Griggs. 1976. The geographic and ecological distribution of big sagebrush and other woody Artemisias in Montana. Proc. Montana Acad. Sci. 36:56-79.

Pavlik, B.M. 1980. Patterns of water potential and photosynthesis of desert sand dune plants, Eureka Valley, California. Oecologia 46:147-154.

Peet, R.K., and O.L. Loucks. 1977. A gradient analysis of southern Wisconsin forests. Ecol. 58:485-499.

Robertson, D.R., J.L. Nielsen, and N.H. Bare. 1966. Vegetation and soils of alkali sagebrush and adjacent big sagebrush ranges in North Park, Colorado. J. Range Manage. 19:17-20.
Sabinske, D.W. and D.H. Knight. 1978. Variation within the sagebrush vegetation of Grand Teton National Park, Wyoming. Northwest Sci. 52:195-204.

Shumar, M.L. 1983. Sagebrush distributions on the Idaho National Engineering Laboratory. p. 157-161. In: O.D. Markham. (ed.) Idaho National Engineering Laboratory Radioecology and and Ecology Programs 1983 Progress Report. ID-12098. Nat. Tech. Info. Serv. Springfield, Va.

Tevis, L., Jr. 1958. A population of desert ephemeral germinated by less than one inch of rain. Ecol. 39:688-695.

Tiedemann, A.R., and T.D. Anderson. 1971. Rapid analysis of total sulfur in soils and plant material. Plant and Soil 35:197-200.

Tisdale, E.W., and M. Hironaka. 1981. The sagebrush-grass region: A review of the ecological literature. Univ. of Idaho For., Wildl. and Range Exp. Sta. Bull. No. 33.

West, N.E., R.J. Tausch, K.H. Rea, and P.T. Tueller. 1978. Taxonomic determination, distribution, and ecological indicator values of sagebrush within the pinyon-juniper woodlands of the Great Basin. J. Range Manage. 31:87-91.

Winward, A.H. 1970. Taxonomic and ecological relationships of the big sagebrush complex in Idaho. Ph.D. Diss. Univ. of Idaho. Moscow.

Winward, A.H., and E.W. Tisdale. 1977. Taxonomy of the Artemisia tridentata complex in Idaho. Univ. of Idaho Forest, Wildl. and Range Exp. Sta. Bull. No. 19 